УДК 801.8

DOI 10.25205/1818-7935-2019-17-4-6-11

\title{
On Linguoculturology and Cultural Linguistics
}

\author{
Bert Peeters \\ Australian National University \\ Canberra, Australia \\ Universiteit Antwerpen \\ Antwerpen, Belgium
}

Abstract

Few Western scholars are likely to be aware that behind the noun linguoculturology and the adjective linguoculturological lie realities they may not be entirely familiar with. Most will no doubt unhesitatingly assume that the labels in question are no more than a different way of referring to what, in Western Europe, the Americas, and Australia / New Zealand, is called cultural linguistics. Yet, what we are witnessing here is anything but terminological variation. It is terminological indifference of a kind that is common in most areas of scholarly activity, not in the least among linguists, many of whom use identical terms for different purposes, and different terms for identical purposes, thereby stifling progress instead of inviting dialogue, and promoting indifference rather than engaging in collaborative efforts. Mizin and Korostenski (2019) take the translators of two recent papers to task for the kind of terminological indifference referred to above. Both Sharifian (2015) and Peeters (2017) were originally written in English and then translated into Russian to draw the attention of post-Soviet scientists to developments in cultural linguistics in the Western world. I revisit each of these texts, before reaching the conclusion that we need to increase awareness in both directions. The ongoing translation of important programmatic texts from English into Russian and vice versa is crucial, and so is the publication of introductory materials, critical assessments, and terminological dictionaries. They will allow Western linguists to further familiarize themselves with the theoretical underpinnings and empirical findings of linguoculturology, and help post-Soviet science transcend the geographic and ideological area to which it is still largely confined. The publication, in different issues of the 2020 volume of this journal, of revised versions of the four introductory lectures on the Natural Semantic Metalanguage approach I had the pleasure of delivering at Novosibirsk State University in June 2019 will hopefully help achieve some of the cross-fertilization contemporary cultural linguistics so badly needs.

Keywords

Linguoculturology, Cultural Linguistics, Natural Semantic Metalanguage, terminological variation, terminological indifference, scientific synergies

For citation

Peeters, Bert. On Linguoculturology and Cultural Linguistics. Vestnik NSU. Series: Linguistics and Intercultural Communication, 2019, vol. 17, no. 4, p. 6-11. DOI 10.25205/1818-7935-2019-17-4-6-11

\section{О лингвокультурологии и культурологической лингвистике}

\section{Берт Петерс}

Австралийский национальный университет

Канберра, Австралия

Антверпенский университет

Антверпен, Бельгия

Аннотация

Мало кто из западных исследователей осознает, что за существительным лингвокультурология и прилагательным лингвокультурологичекий лежит область исследований, с которой они, возможно, не совсем знакомы. 
Большинство из них безо всяких колебаний сочтут, что русский термин - лишь другой способ называть ту область лингвистики, которую в Западной Европе, в Северной и Южной Америке, Австралии и Новой Зеландии называют cultural linguistics (букв. культуральной лингвистикой, но обычно культурологической лингвистикой). Тем не менее, наблюдаемое расхождение совершенно нельзя трактовать как вариативность терминологии, как оговорку. Это есть в некотором роде свидетельство терминологической «глуxотыl», которая присуща многим гуманитариям, и далеко не в последнюю очередь лингвистам, и это несмотря на то, что сам предмет их исследования - язык и слово - требует от них более, чем от кого-либо другого, осознавать важность точной терминологии. Используя идентичные термины для обозначения разных явлений и разные термины для указания на одно и то же, лингвисты приносят больше вреда, чем пользы, не способствуют диалогу и взаимодействию между научными сообществами, усложняют их. Именно за такую терминологическую глухоту Мизин и Коростенский (2019) критикуют переводчиков двух недавних работ - Sharifian (2015) и Peeters (2017) - переведенных с английского языка на русский, чтобы привлечь внимание ученых на постсоветском пространстве к достижениям западной культурологической лингвистики. В данной статье автор возвращается к этим текстам и приходит к выводу, что мы действительно остро нуждаемся в приведении терминологии к общему знаменателю. Перевод в обоих направлениях важнейших текстов играет в этом ключевую роль, так же как и публикация разного рода критических материалов и терминологических словарей. Они позволят западным лингвистам составить более четкое представление о теоретических основаниях и эмпирических исследованиях в области лингвокультурологии, а лингвистика постсоветского пространства сможет преодолеть географические и идеологические барьеры, которые до сих пор ограничивают ее. Хочется верить, что поочередная публикация в «Вестнике» на протяжении 2020 г. четырех статей на основе базовых лекций о естественном семантическом метаязыке (NSM), с которыми автор выступил в Новосибирском государственном университете в июне 2019 в качестве приглашенного профессора, будет способствовать научному взаимооплодотворению современных национальных школ культуро-ориентированной лингвистики и лингвокультурологии.

Ключевые слова лингвокультурология, культурологическая лингвистика, естественный семантический метаязык (ЕСТ), терминологическая вариативность, терминологическая глухота, научная синергия

Для цитирования

Peeters, Bert. On Linguoculturology and Cultural Linguistics // Вестник НГУ. Серия: Лингвистика и межкультурная коммуникация. 2019. Т. 17, № 4. C. 6-11. DOI 10.25205/1818-7935-2019-17-4-6-11

In "Western Cultural Linguistics" [Mizin \& Korostenski, 2019], labels such as linguoculturology and linguoculturological are unlikely to be singled out for closer scrutiny. Built on transparent Greek and Latin roots, they are generally thought to be beyond the need for definition. Even when no further clarification is provided, readers will believe they have a sound understanding of the kind of scientific endeavour the two terms seek to convey. Indeed, how could one not see that they refer to the linguistically informed study of the intricate links between languages, cultures, and thought? A good example of this "superficial" approach, which takes formal transparency for granted, can be found in a recent paper by Maia Kikvadze [Kikvadze, 2018] on "Linguoculturological aspects of the study of Samkhruli (Southern) floronymic phrasal units". The noun linguoculturology does not appear once; the adjective is part of the title and of the concluding sentence, in which the author defiantly states that there are good prospects for further research on Samkhruli floronymic phraseological units, from a linguoculturological, psycholinguistic and sociolinguistic perspective. Kikvadze's paper is fairly short, and not even one of the references in the final bibliography refers to linguoculturology as it is understood in recent Russian scholarship. The fact that the author is a specialist of Georgian philology affiliated with a Georgian State University is probably not totally irrelevant here.

Regrettably, few Western scholars appreciate that behind the terms linguoculturology and linguoculturological lie realities they may not be entirely familiar with. Most will no doubt unhesitatingly assume that the labels in question are quite simply another way of referring to what, in Western Europe, the Americas, and Australia / New Zealand, is called cultural linguistics. Yet, what we are witnessing here is anything but a case of terminological variation. It is terminological indifference of a kind that is widespread in most areas of scholarly activity, but especially among contemporary linguists, who, because of their preoccupation with language and languages, ought to be 
aware more than any others of the importance of getting their terminology right. Unfortunately, terminological awareness is something linguists are generally not very good at. Their use of different terms for identical purposes, and of identical terms for different purposes, creates Babylonian confusion. Rather than inviting dialogue, it stifles progress. It cultivates indifference rather than mutual collaboration. Mizin and Korostenski [2019], whose paper is itself a (drastically shortened) English version of a Ukrainian original [Мізін, 2019], take the translators of two recent papers to task for the kind of terminological indifference referred to above. Both Sharifian [2015] and Peeters [2017] were originally written in English and subsequently translated into Russian to draw the attention of post-Soviet scientists to developments in cultural linguistics in the Western world.

Sharifian [2015] is the translation, by I. Lebedeva, of a book chapter titled "Cultural Linguistics and Intercultural Communication" [Sharifian, 2013]. It provides a first-hand description of "Cultural Linguistics", as understood by Farzad Sharifian, and an account of the development of what the author refers to as an "emerging field", then examines how it can be applied to studies of problems in intercultural communication. For a short time, "Cultural Linguistics" was known as "cultural linguistics" (with lower case initials), but this practice has now been abandoned. The use of upper rather than lower case may look like a purely cosmetic change, but it is not: it is now possible to see "cultural linguistics" (with lower case initials) as a common denominator for a variety of approaches linked by a shared interest in the complex relations between language and culture, one of which is "Cultural Linguistics" à la Sharifian.

In his latest book, Sharifian [2017. P. 2] explains that he uses the term Cultural Linguistics "to refer to a recently developed discipline with multidisciplinary origins that explores the relationship between language and cultural conceptualisations". What Sharifian refers to as Cultural Linguistics, and what I prefer to identify as CULTURAL LINGUISTICS [Peeters, 2016, 2017], recognizes that many features of human languages are "entrenched or embedded" [ibid.] in such cultural conceptualizations. The latter are the tools CULTURAL LINGUISTICS uses to study aspects of cultural cognition and its instantiation in language; they include at least cultural categories, cultural metaphors, and cultural schemas - although I suspect this to be an open-ended list [for definitions, see Mizin \& Korostenki, 2019. P. 9-10; for more details and further references, see Sharifian, 2017a, 2017b].

From an epistemological point of view, the main feature of CULTURAL LINGUISTICS is its multidisciplinarity, i.e. its keenness to present new, interdisciplinary perspectives on the intersection between culture, cognition, and language. CULTURAL LINGUISTICS promotes research that seeks to advance our understanding of cultural conceptualizations of experience in various features of human languages from diverse, yet at the same time complementary, disciplines as wide-ranging as crosscultural pragmatics, anthropological linguistics and cognitive psychology. CULTURAL LINGUISTICS therefore appears to be a lot more ambitious in its undertakings than most if not all Russian forms of cultural linguistics, including linguoculturology. Mizin and Korostenski [2019. P. 7] argue that I. Lebedeva's translation of Sharifian's article is inaccurate because it refers to the latter's approach as Culturological Linguistics. Culturology, they argue, is mainly a "Soviet 'product' that has nothing in common with Cultural Linguistics". This is arguably an overstatement. Nonetheless, Mizin and Korostenski [2019. Ibid.] are right in expressing their amazement at the fact that, even under current globalization processes, "the two powerful scientific disciplines, [which] emerged almost simultaneously in different parts of the world and have a common goal of research, can be developing in isolation from one another", and they observe that "this isolation has played a cruel joke with Cultural Linguistics which remains practically unknown to post-soviet linguists" [Ibid. P. 8]. The opposite is of course equally true: for most CULTURAL LINGUISTS (i.e. disciples and associates of Sharifian), linguoculturology is terra incognita: in the two books and two edited collections published by Sharifian [2011, 2015, 2017a, 2017b] on cultural linguistics at large and CULTURAL LINGUISTICS in particular, the terms linguoculturology and linguoculturological do not appear.

One of the papers in Sharifian [2017a] is a reprint of Peeters [2016]; translated into Russian by O. Dubrovska and published as Peeters [2017], it is the second of the two translations singled out for comment by Mizin and Korostenski [2019. P. 7]. They highlight the "rather professional level" 
of the Russian translation of Peeters [2016], but then accuse the translator of methodological inaccuracy and linguistic incompetence: "O. Dubrovska translated the term Cultural Linguistics as Linguo-culturology - they are two different subjects". Peeters [2016] was meant as an attempt to answer the question whether the author's own approach, known as applied ethnolinguistics, can be thought of as a form of CULTURAL LINGUISTICS (à la Sharifian) or whether, like the latter, it is a different approach within the broader field of (all forms of) cultural linguistics. A recent by-product of the Natural Semantic Metalanguage (NSM) approach, associated with the work of the most formidable linguistic tandem of all times, Cliff Goddard and Anna Wierzbicka, applied ethnolinguistics was developed without reference to Sharifian's CULTURAL LINGUISTICS and makes prolific use of the term cultural value, which it sees as absolutely fundamental to its endeavours. Oddly enough, in CULTURAL LINGUISTICS, the term cultural value appears to be used rather sparingly, and not at all in a technical sense. Even though CULTURAL LINGUISTICS does acknowledge the importance of cultural values (to the extent that detailed study of culturally specific categories, metaphors, schemas, etc. may lead to a more precise understanding of the cultural values upheld in particular language communities), there seems to be little prospect for an eventual amalgamation. Rather, it is argued that applied ethnolinguistics is part of a broader field of (different approaches to) cultural linguistics, where, together with CULTURAL LINGUISTICS à la Sharifian, it is able to provide a useful methodology for the study of language and cultural values.

The hypothesis on which much of my own work in applied ethnolinguistics is built is that judicious exploitation of selected resources of the foreign language in the (advanced) foreign language classroom is likely to facilitate and clear the path for subsequent immersion in a foreign culture. These selected resources include "certain language-specific 'key' words, recurrent colloquial phrases, phraseological units, conversational routines, and other culture-revealing lingual units and forms which together build what in Russian linguistic writings is referred to as either 'linguaculture' or the "lingual picture of the world", which is how Rivlina [2010. P. 9] describes the linguistic evidence linguoculturologists also take a special interest in. It could be argued that linguoculturology, too, is a form of cultural linguistics (in the broadest meaning of the term), like Sharifian's CULTURAL LINGUISTICS and my own applied ethnolinguistics.

About the terms linguaculture and lingual picture of the world, both of which are used in Russian scholarship, Rivlina (ibid.) writes that they are "regrettably absent in the international globalization of English research". Rivlina is obviously unfamiliar with studies such as Friedrich [1986] and Agar [1994]; the term linguaculture is used by the former, the almost identical term languaculture has been popularized by the latter. In my own work, I use Agar's term (languaculture) rather than Friedrich's (linguaculture), as it is closer to the one which, following in the footsteps of Galisson [1991], I adopt in my writings in French, viz. langue-culture. I acknowledge, though, with Gamaroff [1997], that linguaculture may be "easier to pronounce". However, languaculture remains closer to its component parts: "whenever you hear the word language or the word culture, you might wonder about the missing half. [...] 'Languaculture' is a reminder" [Agar, 1994. P. 60].

The message coming out of this position paper should be clear: we badly need to create more synergies between Western and post-Soviet approaches to cultural linguistics. The two sides need to work harder to acknowledge one another, learn from one another, enrich one another. Whether this can eventually lead to a common metalanguage and common definitions of basic terms remains to be seen. For the time being, the ongoing translation of important programmatic texts in both directions is crucial, and so is the publication of introductory materials, critical assessments, and terminological dictionaries (e.g. an English / Russian dictionary of Cultural Linguistics and Linguoculturology). These are the resources we need to allow Western linguists to further familiarize themselves with the theoretical underpinnings and empirical findings of linguoculturology, and to help post-Soviet science transcend the geographic and ideological area to which it is still largely confined.

The publication, in different issues of the 2020 volume of this journal, of revised versions of the four introductory lectures on the Natural Semantic Metalanguage approach I had the pleasure of 
delivering at Novosibirsk State University during a three-month visit completed in June 2019 at the invitation of Michèle Debrenne, whose administrative portfolio at NSU includes the promotion of academic exchanges of staff and students, will hopefully help achieve some of the cross-fertilization contemporary cultural linguistics (in the broadest sense) so badly needs. The titles of the papers that will be published are as follows:

1. Natural Semantic Metalanguage: What is it and what is it good for?

2. Breaking through the shame barrier with simple cross-translatable words

3. Minimal Language: NSM "taken out of the lab"

4. Iskrennost' for foreigners: The benefit of "pedagogical scripts"

The second of the original four lectures was based on a presentation that has in the meantime been published elsewhere [Peeters, 2019] and that could therefore not be included by virtue of the journal's editorial policy. It has been replaced with a comparable presentation that does not deconstruct the ethnopsychological personhood construct mind, but that demonstrates how much can be gained from a comparable deconstruction of the equally reified and falsely universal concept of shame. There is nothing universal about shame, except the way in which it can be linguistically described, for the joint benefit of cultural insiders and outsiders alike. In my view, there is only one way in which this can be achieved: we need a proper tool, and that tool is NSM.

It is my understanding that the work of Anna Wierzbicka, Cliff Goddard, and their collaborators is highly appreciated in Russian academic circles. Informal conversations at NSU suggest that the original English version of Wierzbicka's book on cultural key words [1997] appears to be particularly valued. NSM has come a long way in the meantime. The primary aim of the publication of the lecture series will be to make Russian students and scholars aware of some of the more recent developments that have occurred in the NSM approach, and to encourage them to actively engage with it in their own work. NSM is by no means a substitute for linguoculturology, but it can become an additional tool. It is hoped that increased familiarity with the ins and outs of the NSM approach will act as an incentive for further empirically based research into the languages and cultures of the world, and perhaps for joint ventures between different approaches to cultural linguistics. If it does, cultural linguistics in general and linguoculturology in particular have a lot to look forward to.

\section{References}

Agar, M. Language Shock: Understanding the Culture of Conversation. New York, William Morrow, 1994, $284 \mathrm{p}$.

Friedrich, P. The Language Parallax: Linguistic Relativism and Poetic Indeterminacy. Austin, University of Texas Press, 1986, xii +192 p.

Galisson, R. De la langue à la culture par les mots [From language to culture through words]. Paris, Clé international, 1991, $191 \mathrm{p}$.

Gamaroff, R. African spaces in culture and communication: Implications for education. Conference paper, Africa in a Changing World, Institute of Africa, Moscow, 1-3 October 1997. URL: http:/grammargraph.wordpress.com/2010/06/09/african-spaces-in-culture-and-communication-implications-for-education/ (accessed 15.07.2013).

Kikvadze, M. Linguoculturological aspects of the study of Samkhruli (Southern) floronymic phrasal units. In : O. Soutet, S. Mejri and I. Sfar (eds.). La phraséologie: théorie et applications. Paris, Champion, 2018, p. 183-193.

Mizin, K., Korostenski, J. "Western" Cultural Linguistics and "Post-Soviet" Linguoculturology: Causes of parallel development. Лінгвістичні студї, 2019, № 37, p. 7-13. DOI 10.31558/ 1815-3070.2019.37.1.

Мізін, К. І. Точки дотику культурної лінгвістики і лінгвокультурології: теоретичні підвалини та методологічний інструментарій. In: Людино- й культурознавчі пріоритети сучасного мовознавства: напрями, тенденції та міждисциплінарна методологія. Гол. ред. К. І. Мізін. Переяслав-Хмельницький; Кременчук, ПП Щербатих О. В., 2019, p. 71-84. (in Ukr.) 
Peeters, B. Applied ethnOlinguistics is cultural linguistics, but is it CUltural Linguistics? International Journal of Language and Culture, 2016, № 3 (2), p. 137-160. DOI 10.1075/ ijolc.3.2.01pee. Translated into Russian as Peeters (2017).

Peeters, B. ПРИКЛАДНАЯ ЭТНОЛИНГВИСТИКА - это лингвокультурология, но лингвОКУльтУРОЛОГИЯ ли? Жанры речи, 2017, № 15, p. 37-50. Russian translation of Peeters (2016). DOI 10.18500/2311-0740-2017-1-15-37-50

Peeters, B. The English ethnopsychological personhood construct mind "deconstructed" in universally intelligible words. Critical Studies in Languages and Literature, 2019, № 1 (1), p. 61-77. URL: https://www.ejmanager.com/fulltextpdf.php?mno=19899 (accessed 01.09.2019).

Rivlina, A. English-Russian interaction: Refashioning cultural values and assumptions. In: Building Bridges with Languages and Cultures: $14^{\text {th }}$ NATE $/ 7^{\text {th }}$ FEELTA International Conference on Language Teaching. Vladivostok, 2010, vol. 2, p. 8-18. URL: https://www.hse.ru/data/2012/ 02/29/1224397649/Rivlina\%20English-Russian\%20Interaction.pdf (accessed 01.09.2019).

Sharifian, F. Cultural Conceptualizations and Language: Theoretical Framework and Applications. Amsterdam, John Benjamins, 2011, 255 p. DOI 10.1075/clscc.1

Sharifian, F. Cultural linguistics and intercultural communication. In: Language and Intercultural Communication in the New Era. Ed. by F. Sharifian, M. Jamarani. New York, Routledge, 2013, p. 60-79. Translated into Russian as Sharifian (2015b).

Sharifian, F. (ed.). The Routledge Handbook of Language and Culture. New York, Routledge, 2015a, xvi +522 p.

Sharifian, F. Культурная лингвистика и межкультурная коммуникация. Филологические нау$\kappa u, 2015$ b, № 3, p. 80-97. Russian translation of Sharifian (2013).

Sharifian, F. (ed.). Advances in Cultural Linguistics. Cham, Springer, 2017a, xii +745 p. DOI 10.1007/978-981-10-4056-6

Sharifian, F. Cultural Linguistics. Amsterdam, John Benjamins, 2017b, xvii $+171 \mathrm{p}$. DOI 10.1075/clscc.8.

Wierzbicka, A. Understanding Cultures Through their Key Words: English, Russian, Polish, German, Japanese. New York, Oxford University Press, 1997, 328 p.

Date of submission

Материал поступил в редколлегию 02.09.2019

\section{Information about the Author / Сведения об авторе}

Bert Peeters, $\mathrm{PhD}$, Associate Professor, Australian National University (Canberra, Australia) and Universiteit Antwerpen (Antwerpen, Belgium)

Петерс Берт, $\mathrm{PhD}$, доцент, Австралийский национальный университет (Канберра, Австралия), Антверпенский университет (Антверпен, Бельгия)

Bert.Peeters60@gmail.com

ORCID 0000-0001-8422-4156 